\title{
Pasture damage from spot-sprayed herbicides
}

\author{
K.C. Harrington ${ }^{1}$, H. Ghanizadeh ${ }^{1}$, C. Moyo ${ }^{1}$, P.D. Kemp ${ }^{1}$ and J.P.J. Eerens ${ }^{2}$ \\ ${ }^{1}$ Institute of Agriculture and Environment, Massey University, Palmerston North, New Zealand, \\ ${ }^{2}$ Bayer New Zealand Ltd, 30 B Aspenleigh Drive, RD 3, Hamilton, New Zealand \\ Corresponding author:K.Harrington@massey.ac.nz
}

\begin{abstract}
Spot-spraying weeds in pastures enables the use of herbicide that would be too harmful to pasture if boom-sprayed. However, some herbicides are more damaging than others. To quantify this damage, a range of spot-spraying treatments was applied to ryegrass/ white clover pastures. Four herbicide treatments were compared, each at two application rates and two sizes of sprayed patch. Applications of either clopyralid or a triclopyr/ picloram mix resulted in total removal of white clover from the sprayed patches but these patches remained covered in perennial ryegrass. Metsulfuron also removed all white clover but also severely damaged the perennial ryegrass, although some grass cover remained due to survival of browntop. Residues of these treatments suppressed seedlings of white clover and weeds for many weeks after application. Glyphosate treatments resulted in the most bare soil. White clover recovered most rapidly in glyphosate-treated areas, mainly by lateral spread of stolons, but weed species also established rapidly.
\end{abstract}

Keywords white clover, herbicides, ryegrass, spot-spraying, pasture, weed control.

\section{INTRODUCTION}

Spot-spraying of weeds when their density is low will reduce herbicide use compared to boomspraying (James et al. 1997). In New Zealand, farmers normally use phenoxy herbicides (e.g. 2,4-D or MCPA) for broadcast application on pastures. New Zealand pastures are typically a sown mixture of both perennial ryegrass (Lolium perenne) and white clover (Trifolium repens) (Kemp et al. 2000) and often many other volunteer species. Some of the herbicides typically used for spot-spraying weeds in these pastures, such as metsulfuron, picloram, triclopyr, clopyralid, and dicamba, are highly toxic to white clover and can have a long residual life in the soil (Tomlin 2000) so may cause undesirable damage to the pasture if used to kill weeds.

Spot-spraying of herbicides is traditionally done either with a knapsack sprayer or a hand- held spray gun attached by hose to a tank of herbicide mounted on a vehicle. Herbicide application with spray guns or knapsack sprayers is often not very precise with some chemical hitting and killing non-target vegetation around the weed. The resultant bare ground is likely to be colonised by opportunistic weeds of lower or no forage value (McConnaughay \& Bazzaz 1987). The initial colonisation of bare ground is limited by the availability of seed and vegetative plant propagules, and hence there is a general tendency for species that are common in the sward to also become the most successful gap colonisers (Reader \& Buck 1991; Bullock et al. 1995).

The residual life of herbicides in the soil will influence the recovery time of pastures. Herbicides break down through either chemical 
or microbial degradation (Youngson et al. 1967; Riley \& Morrod 1977; Pons \& Barriuso 1998). Although some previous research on spotspraying of pasture weeds has assessed effects on pasture, most of the focus has been on the effectiveness of herbicides in killing target weeds at different dosage rates (Taylor 1973; Martin et al. 1988). Little information is available on the time it takes for damaged pasture to recover from spot treatments of herbicides and the influence of gap size on the recovery time. Therefore, the experiments reported in this paper were designed to quantify the impact of some of the main spotspraying treatments on pasture plants that are exposed to herbicide around the target weed.

\section{MATERIALS AND METHODS}

\section{Study site}

Field experiments were conducted in an established 10-year-old perennial ryegrass and white clover pasture at the Moginie Pasture and Crop Research Unit of Massey University, Palmerston North, from December 2004 to September 2005. Weather data for the period of the experiments are summarised in Table 1.

Table 1 Total rainfall and average maximum daily temperatures for the duration of the experiments

\begin{tabular}{lcl}
\hline Month & $\begin{array}{l}\text { Rainfall } \\
(\mathrm{mm})\end{array}$ & $\begin{array}{l}\text { Temperature } \\
\left({ }^{\circ} \mathrm{C}\right)\end{array}$ \\
\hline December 2004 & 154.6 & 18.5 \\
January 2005 & 68.2 & 22.2 \\
February 2005 & 28.4 & 25.2 \\
March 2005 & 50.4 & 22.3 \\
April 2005 & 52.2 & 18.3 \\
May 2005 & 85.4 & 16.7 \\
June 2005 & 65.0 & 13.2 \\
July 2005 & 87.6 & 13.9 \\
August 2005 & 44.4 & 15.4 \\
September 2005 & 104.2 & 17.0 \\
\hline
\end{tabular}

Soil tests prior to treatment indicated a mean $\mathrm{pH}$ of $5.6\left(\mathrm{CaCl}_{2}\right)$, an Olsen $\mathrm{P}$ of $50.8 \mu \mathrm{g} \mathrm{P} / \mathrm{g}$, and the $\mathrm{K}, \mathrm{Mg}$, and Ca levels averaged $0.68,1.22$, $5.5 \mathrm{me} / 100 \mathrm{~g}$ respectively. Soil organic matter averaged $5.5 \%$ and the soil type was a Tokomaru silt loam. Plots were fertilised once in November 2004 with $250 \mathrm{~kg} / \mathrm{ha}$ Crop Master 15 with an N, P, K, S composition of 15.2 - 10 - 10 - 7.7, respectively. Prior to herbicide treatments being applied, point analysis across the site showed that the pasture had an average cover of $12.6 \%$ white clover and $0.7 \%$ weeds, including docks (Rumex spp.), catsear (Hypochaeris radicata) and dandelion (Taraxacum officinale).

\section{Experiment 1 - Pasture damage}

The herbicides assessed and their application rates (g ai/ha) were: glyphosate (360 \& 1080), a triclopyr/picloram mixture (500/250 \& 1500/750), clopyralid (600 \& 1800), and metsulfuron (30 \& 90). The products used were Roundup G2 (glyphosate as isopropylamine salt); Tordon Gold (triclopyr/picloram as amine salts), Versatill (clopyralid as amine salt) and Escort (metsulfuron as methyl ester) respectively. The lower doses were applied in water at a rate of $1000 \mathrm{~L} /$ ha considered to equate to a standard spot-spraying rate expected from back-pack spraying, whereas higher doses were applied in water at a rate of $3000 \mathrm{~L} / \mathrm{ha}$ to simulate overdosing as might occur with a pressurised spray gun from a tractor. Each rate was applied to two different patch sizes (either $30 \mathrm{~cm}$ diameter $(0.07$ $\mathrm{m}^{2}$ ) or $80 \mathrm{~cm}$ diameter $\left(0.5 \mathrm{~m}^{2}\right)$ ) to determine the effect of gap size on the time it takes for pasture to recover.

There were two untreated controls (one for each patch size), and each treatment was replicated six times to give a total of 108 patches. Herbicides were applied to the patches on 6 December 2004. Treatments were allocated to patches using a randomised complete block design with six blocks and 18 treatments in each block for Experiment 1. Blocking was based on the white clover content of each patch, measured by point analysis as explained below. The distance between patches was $2.5 \mathrm{~m}$ from centre to centre. Treatments were applied using plastic circles to define the edge of patches and quantities of spray solution were measured into a small container and all of this was applied evenly across the patch with a hand-held sprayer. 
The botanical composition of each patch was measured monthly for 6 months using point analysis ( 100 points per big patch and 60 points per small patch). Species were identified individually and overall composition was categorised into grass, white clover, weed and bare ground. The pasture quantity was estimated in each patch by taking five measurements per patch each month using a pasture capacitance probe, which were averaged to give a single figure. The pasture was fenced off for the duration of the experiment to remove any influence of livestock on patch recovery and mown on occasions (after measurements had been made) to a height of $5 \mathrm{~cm}$.

\section{Experiment 2- Herbicide soil residues}

At the same site and time as Experiment 1, another experiment was conducted with three replicates of treatments with large patches $(80 \mathrm{~cm}$ diameter $\left.\left(0.5 \mathrm{~m}^{2}\right)\right)$ for clopyralid, metsulfuron, and triclopyr/picloram applied at both rates used in Experiment 1 as well as the untreated control to provide samples for a bioassay study to determine indirectly the persistence of these herbicides. Three soil cores $(2.5 \mathrm{~cm}$ diameter, $5 \mathrm{~cm}$ depth) were taken randomly from each patch fortnightly. Each soil core was put into a separate $200 \mathrm{~cm}^{3}$ pot after root fragments were removed from the soil. The pots were $30 \%$ filled with vermiculite before the soil was added to reduce the amount of soil required from each patch. Each pot was sown with 35 white clover seeds, and kept in a glasshouse with mean monthly temperatures ranging from a low of $13.9^{\circ} \mathrm{C}$ in July to a high of $23.3^{\circ} \mathrm{C}$ in January. Subsurface irrigation kept the pots moist, though this was occasionally supplemented by overhead irrigation. After 5 weeks, the seedlings were harvested and their fresh weight recorded. Soil samples continued to be taken from the field at fortnightly intervals until no difference in herbage growth (as a proxy for presence of residual herbicide) was measured between the treatments and the untreated control.

\section{Statistical analysis}

The natural $\log$ of the response variables was used to satisfy model assumptions of normality.
Because there were a number of zero values in the data, 1.5 was added to every observation to allow the use of log transformation using $\log (\mathrm{Y}+1.5)$ where Y denotes the response variable. Version 9.1 of SAS software (SAS Institute 2004) was used for all analyses of variance, and significance was set at $\mathrm{P}<0.05$ for all comparisons.

\section{RESULTS}

\section{Experiment 1}

Metsulfuron was highly damaging to pasture, causing death of white clover at both the high and low rates applied (Figure 1). Application of metsulfuron also led to suppression of grass species, with perennial ryegrass being much more susceptible than other grass species such as Agrostis capillaris. The patches treated with the higher rate were only fully re-colonised by grass 5 months after treatment, with no white clover or weeds colonising gaps created by metsulfuron. The large metsulfuron-treated patches took longer to recover and had significantly more bare ground than smaller patches until March, 3 months after treatment $(\mathrm{P}<0.05)$. No weeds re-colonised any of the patches treated with metsulfuron up to 9 months after treatment.

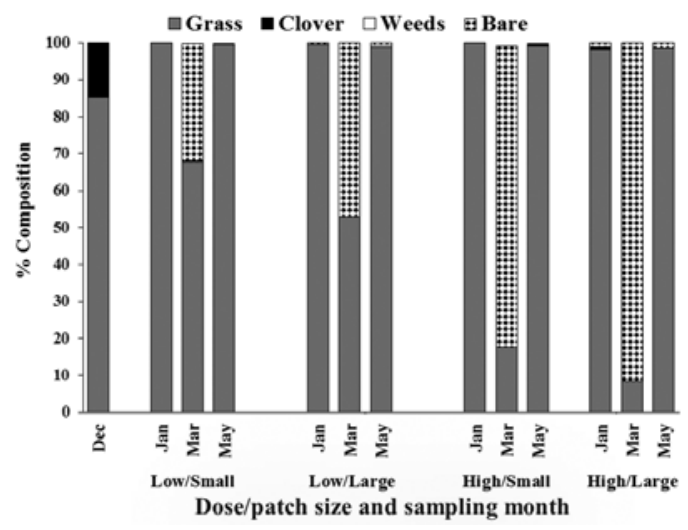

Figure 1 Composition of pasture cover (classified as either grass, clover, weeds or bare) over time (mean of six replicates) of small and large patches treated on 6 Dec 2004 with low or high rates of metsulfuron in Experiment 1. The initial composition before treatment is shown by the bar on the left. 
All glyphosate-treated patches had at least $94 \%$ bare ground within a month of treatment, with grasses affected more severely than the white clover (Figure 2). The bare ground was rapidly colonised by weeds such as Scotch thistle (Cirsium vulgare), docks, turf speedwell (Veronica serpyllifolia), pennyroyal (Mentha pulegium), dandelion, catsear, hawkbit (Leontodon taraxacoides), black nightshade (Solanum nigrum), annual mouse-ear chickweed (Cerastium glomeratum) and chickweed (Stellaria media). The weeds were most common in larger gaps while the smaller gaps were rapidly colonised by white clover stolons spreading from surrounding unsprayed pasture. The white clover recovered more rapidly within the first 2 months at the lower rate of glyphosate than the higher rate $(\mathrm{P}<0.05)$, due partly to regrowth of some sprayed stolons at the lower rate. Most white clover regrowth was observed to be from stolons, not seedlings.

Clopyralid and triclopyr/picloram were similar to each other in their effect on vegetation. Both these herbicide treatments completely removed white clover from most patches, and the white clover content never recovered to a level above $1.7 \%$ for any treatment throughout the 9-month experiment period (data not shown). The effect on white clover was the same

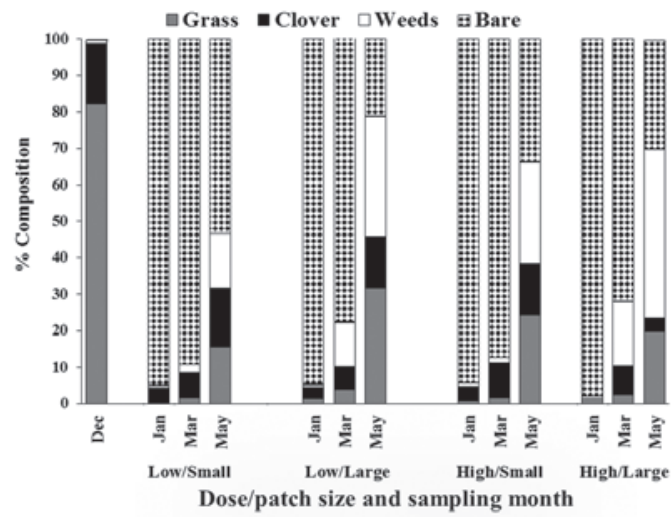

Figure 2 Composition of pasture cover (classified as either grass, clover, weeds or bare) over time (mean of six replicates) of small and large patches treated on 6 Dec 2004 with low or high rates of glyphosate in Experiment 1.

regardless of patch size or rate of application, as white clover was effectively removed from all patches and it did not recolonise. However, there was no effect on grass growth, and no weeds occurred in the sprayed patches, thus all patches were $100 \%$ grass.

Pasture probe measurements showed that there were negligible effects on production from patches sprayed with clopyralid or triclopyr/ picloram due to the tolerance of perennial

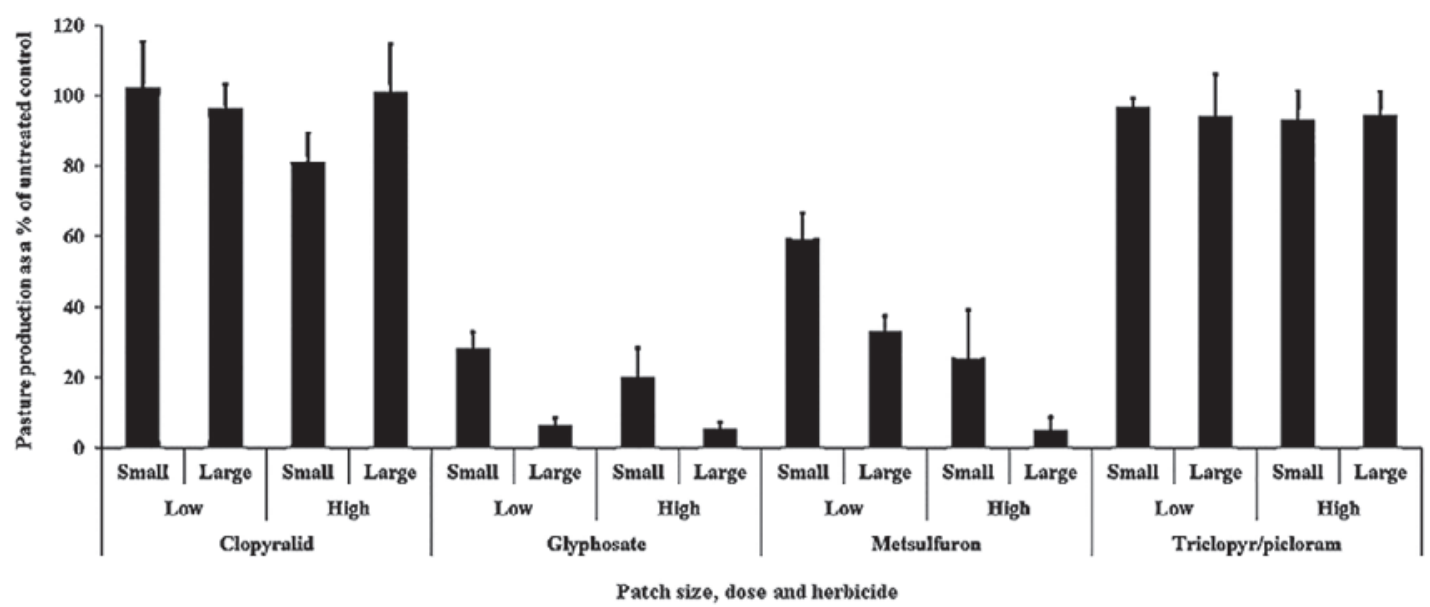

Figure 3 Pasture production as a percentage of untreated control at 2 months after the application of herbicides (mean of 6 patches) in Experiment 1. Vertical bars represent standard errors of the mean. 
ryegrass to these herbicides (Figure 3). Pasture production declined to as little as $1.2 \%$ of the untreated control in patches treated with glyphosate, while production was as low as $15 \%$ and $47 \%$ of the untreated control for high and low rates of metsulfuron, respectively.

\section{Experiment 2}

Metsulfuron was the least persistent of the three soil-active herbicides tested, with adverse effects on white clover seedlings ranging from 3-6 weeks (Figure 4). Soil samples taken 6 weeks after treatment resulted in the lower rate of metsulfuron giving a white clover yield 20\% greater than the untreated control, while the yield from soil treated with the higher rate was not different from the untreated control. The herbage yield from the bioassays of metsulfuron sampled on dates greater than 6 weeks was either higher or equal to the untreated control until 25 weeks after treatment. Clopyralid at both rates caused significant depression of white clover seedling growth for 18 weeks after treatment (Figure 5), with the higher rate suppressing white clover seedling growth by over $80 \%$ for the first 12 weeks. Residues of the triclopyr/ picloram treatments persisted longer than the other herbicides (Figure 6). White clover growth for the high rate was still below $10 \%$ of the untreated control up to 15 weeks after treatment with the white clover yield equalling that of the untreated control 30 weeks after treatment. The white clover yield for the low rate took 21 weeks to reach that of the untreated control.

\section{DISCUSSION}

All spot-spraying treatments studied in this work caused detrimental effects to white clover, and some to grasses as well, but the consequences of these effects varied. If weeds had been present in the patches that were sprayed for Experiment 1, bare soil would no doubt have occurred once the weeds died off. The glyphosate treatments provided little residual herbicide activity, which allowed new weeds to establish in the bare soil created by damage to the pasture. This outcome is undesirable given that spot-spraying operations

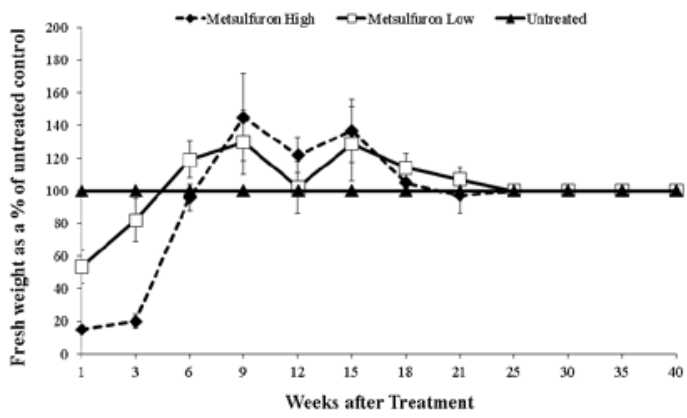

Figure 4 The effect of two rates of metsulfuron on clover seedlings grown in the treated soil at different times after application in Experiment 2. Vertical bars refer to standard errors of the mean.

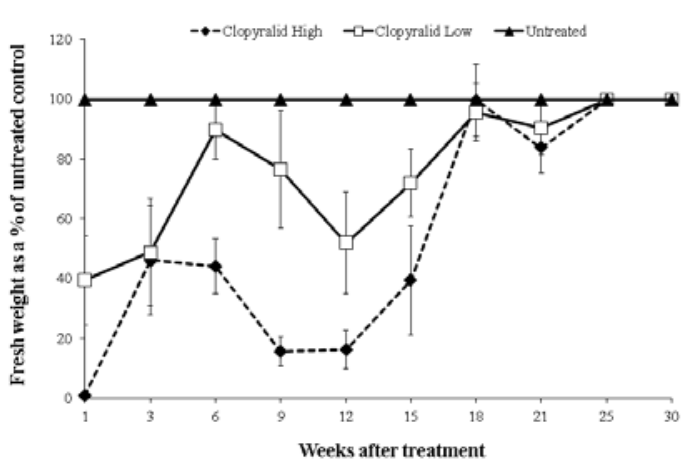

Figure 5 The effect of two rates of clopyralid on clover seedlings grown in the treated soil at different times after application in Experiment 2. Vertical bars are standard errors of the mean.

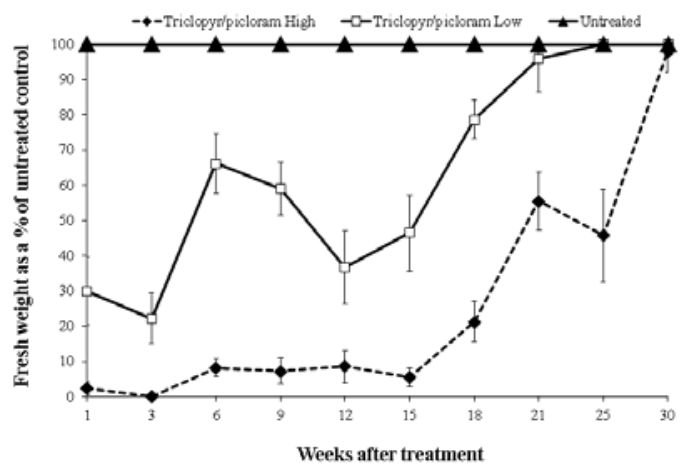

Figure 6 The effect of two rates of triclopyr/picloram on clover seedlings grown in the treated soil at different times after application in Experiment 2. Vertical bars are standard errors of the mean. 
are intended to remove weeds from pasture. Metsulfuron treatments led to less bare soil than for the glyphosate treatments. However, this herbicide severely suppressed the more desirable ryegrass plants in favour of the less desirable browntop as well as killing the white clover. Overall, these effects led to reduced pasture production from treated patches.

In contrast, competitive grass growth in patches treated with clopyralid and triclopyr/ picloram, coupled with the residues of these herbicides within the soil, meant that little colonisation by new weed seedlings occurred in these patches.

One objective of Experiment 1 was to determine how many months would be needed before white clover would recover in sprayed patches. However, white clover became progressively less noticeable in untreated patches in the latter parts of autumn and almost disappeared during winter and early spring, so nothing useful could be concluded about longterm white clover recovery in treated patches. This effect may have been an artefact of the mowing regime used at the site coupled with the normal slow growth of white clover over winter. However, the invasive clover root weevil (Sitona obsoletus) reached the site at this time, and its presence was confirmed based on damage symptoms by one of the authors (JPJE) who worked extensively on the spread of this pest within New Zealand. The work was conducted prior to release of the biological control agent for clover root weevil, Microctonus aethiopoides (Basse et al. 2015). Despite this, the proliferation of white clover in glyphosate-treated plots during the first 6 months after treatment suggested that white clover absence during this period in other patches was due to the treatments and not the weevil.

Recovery of white clover following spotspraying is desirable and is more likely to occur rapidly via lateral growth of stolons from nearby plants than from seedling germination. Thus, keeping the size of patches damaged by spotspraying herbicides as small as possible would be important both for keeping the amount of pasture devoid of white clover to a minimum and also for allowing more rapid recovery from nearby undamaged white clover. Regrowth of white clover appeared to occur mostly from stolon growth following glyphosate treatment in Experiment 1 due to a lack of competition from grasses and a lack of residual herbicide activity. However, it was not observed in patches treated with the other three herbicides during the 6 months after application, before the effects of the clover root weevil began. As the walls of the plastic circles put in place during spraying of patches were $10 \mathrm{~cm}$ high, it is assumed there was very little spray drift on to neighbouring white clover plants. Thus the lack of lateral spread into these treated patches may have been due to translocation of the herbicides back along stolons within the patches, or perhaps the competition from the grasses present and the residues in the soil may have discouraged this lateral spread.

From Experiment 1, clopyralid and a triclopyr/ picloram mixture appear to be better options for spot-treatments in pastures than glyphosate and metsulfuron, as the perennial ryegrass component of sprayed patches is not affected by the former two treatments, and glyphosate allows new weeds to establish. Although the patch size should be kept as small as possible because of poor re-establishment of white clover, Moyo et al. (2014) showed that ragwort (Jacobaea vulgaris) and Scotch thistle can be adequately controlled using translocated herbicides by spraying only the centre of the rosettes, minimising the amount of pasture damage caused.

The relative persistence of triclopyr/picloram, clopyralid and metsulfuron in Experiment 2 was similar to that found by Tran et al. (2015) in a similar experiment conducted at a nearby site in Palmerston North using broom (Cytisus scoparius) as a bioassay species. These authors also found that metsulfuron was much less persistent than either triclopyr/picloram or clopyralid. The increase in white clover seedling growth noted for metsulfuron several months after application was presumably due to hormesis whereby toxic substances at sublethal doses have a stimulatory effect on plant growth (Duke et al. 2006). The lack of weed germination from the bare soil present in some 
of the patches treated with metsulfuron suggested residues persisted long enough to prevent weed seedlings germinating before grasses had recovered sufficiently to cover the bare soil even though this herbicide was less persistent than either triclopyr/ picloram or clopyralid.

\section{REFERENCES}

Basse B, Phillips CB, Hardwick S, Kean JM 2015. Economic benefits of biological control of Sitona obsoletus (clover root weevil) in Southland pasture. New Zealand Plant Protection 68: 218-226.

Bullock JM, Clear Hill B, Silvertown J, Sutton M 1995. Gap colonization as a source of grassland community change: effects of gap size and grazing on the rate and mode of colonization by different species. Oikos 72(2): 272-283.

Duke SO, Cedergreen N, Velini ED, Belz RG 2006. Hormesis: is it an important factor in herbicide use and allelopathy? Outlooks on Pest Management 17(1): 29-33.

James TK, Rahman A, de Jong P 1997. Flazasulfuron for control of ragwort (Senecio jacobaea) in pasture. Proceedings of the 50th New Zealand Plant Protection Conference: 18-21.

Kemp PD, Mathew C, Lucas RJ 2000. Pasture species and cultivars. In: White J, Hodgson J eds. New Zealand pasture and crop science. Oxford University Press, Melbourne, Australia. Pp. 84-99.

Martin P, Thompson A, Rahman A 1988. Spot treatment of ragwort and nodding thistle with DPX-L5300. Proceedings of the 41st New Zealand Weed and Pest Control Conference: 223-225.

McConnaughay KDM, Bazzaz FA 1987. The relationship between gap size and performance of several colonizing annuals. Ecology 68(2): 411-416.
Moyo C, Harrington KC, Kemp PD, Eerens JPJ 2014. Effectiveness of spraying herbicides in the centre compared to all over rosettes of Cirsium vulgare and Jacobaea vulgaris. Proceedings of the 19th Australasian Weeds Conference: 235-238.

Pons N, Barriuso E 1998. Fate of metsulfuronmethyl in soils in relation to pedo-climatic conditions. Pesticide Science 53(4): 311-323.

Reader RJ, Buck J 1991. Control of seedling density on disturbed ground - role of seedling establishment for some midsuccessional, oldfield species. Canadian Journal of Botany-Revue Canadienne De Botanique 69(4): 773-777.

Riley D, Morrod RS 1977. Relative importance of factors influencing the activity of herbicides in soil. Proceedings of the 1976 British Crop Protection Conference - Weeds. Volume 3. Pp. 971-980.

SAS Institute 2004. SAS version 9.1.

Taylor RL 1973. Control of ragwort. Proceedings of the 26th New Zealand Weed and Pest Control Conference: 50-52.

Tomlin CDS ed. 2000. The pesticide manual. 12th ed. British Crop Protection Council, Surrey, UK. 1250 p.

Tran H, Harrington KC, Robertson AW, Watt MS 2015. Relative persistence of commonly used forestry herbicides for preventing the establishment of broom (Cytisus scoparius) seedlings in New Zealand plantations. New Zealand Journal of Forestry Science 45: 6.

Youngson CR, Goring CAI, Meikle RW, Scott HH, Griffith JD 1967. Factors influencing the decomposition of Tordon herbicide in soils. Down to Earth. 23(2): 3-11. 